\title{
3
}

\section{The climate strategies of the oil industry}

Oil companies want to sell as much oil and gas as possible at the highest possible price. Still, a quick glance at the web pages of Shell, ExxonMobil and Statoil (as well as other US and Europeanbased oil companies) reveals significant differences in their perceptions of climate change. What are the strategies adopted by ExxonMobil, the Shell Group and Statoil on the climate issue? Do they merely use different rhetoric to please their clients, consumers and employees, or is the observed difference of a deeper nature? And to what extent have their climate strategies undergone changes during the last decade?

In this chapter, these companies' strategies are assessed and compared with a main focus on a key set of four indicators: (1) the companies' acknowledgement of the prospective problem of a human-induced climate change; (2) their position with regard to the Kyoto Protocol; (3) self-imposed targets and measures to reduce GHG emissions from their own operations; and (4) the long-term implications of their strategy choice, analysed in terms of the degree of reorientation in their core business areas. With regard to the last indicator, an attempt is made to make qualified judgements regarding the extent to which the strategies of the companies to climate change have implied, and will continue to imply, significant changes in their investment decisions.

The climate strategies of ExxonMobil, the Shell Group and Statoil are assessed in relative terms according to a continuum from 'reactive' to 'proactive' strategies. To the extent that companies acknowledge the climate problem, support the Kyoto Protocol, adopt targets and measures to reduce emissions from 
their own operations, and adopt strategies with long-term implications for their mode of operation and business profile, we judge their choice of climate strategy to be proactive.

The climate strategies of ExxonMobil, the Shell Group and Statoil are assessed in the three first sections respectively. To place the companies' climate strategies in a broader context, the more general environmental policy of the companies is briefly assessed in an introductory note to each section of the chapter. The comparison of the strategies chosen by the three companies is carried out in the last section.

\section{ExxonMobil Corporation}

Exxon Corporation started out as Standard Oil in 1882, mainly as a refinery company. In 1888 it began to internationalise its downstream assets, and in the 1920s it invested heavily to become a fully integrated oil company (Estrada et al., 1997). Exxon was one of the 'seven sisters', the oil cartel that controlled the world oil trade in the first half of the twentieth century. In the 1970s, the oil industry was rocked by the Arab oil crisis, and both Exxon and Mobil escalated exploration and development outside the Middle East - in Africa, Asia, the Gulf of Mexico and the North Sea. In November 1999, Exxon and Mobil merged to form ExxonMobil Corporation. Exxon's takeover of Mobil was the largest in history: Mobil shareholders own about 30 per cent of the new company, while Exxon shareholders own about 70 per cent. ExxonMobil is at present the largest multinational company in the world, irrespective of sector. ${ }^{1}$ The immense size of the company is indicated by its financial data: in 2000, the company had a record net income of US $\$ 17.7$ billion with total revenues exceeding US\$230 billion (ExxonMobil, 2000a). The company conducts business in gas, oil, coal and chemicals in more than 200 countries.

Until its merger with Mobil in 1999, Exxon was a strongly hierarchical organisation, with the company's headquarters playing a major role in its decision-making process. For instance, all investments exceeding US\$1 million needed approval from headquarters, although operational managers were given a certain latitude to implement and organise their own programmes and plans as appropriate to the geographical character of their 
areas (Estrada et al., 1997). The merger with Mobil brought about a reorganisation, which has implied a more decentralised structure. With the reorganisation, 'ExxonMobil has entrusted its vast and diverse operations to a slate of business units with global responsibilities. Each company stewards a focused portfolio of operations around the world with a president at the helm and significant authority to run themselves. ${ }^{2}$ Headquarters nevertheless still play a major role in the decision-making process of the company.

\section{ExxonMobil's environmental policy}

ExxonMobil places a strong emphasis on excellence in its environmental performance. The 1999 Health, Safety and Environment (HSE) Progress Report, for instance, states that 'without success in these areas, we cannot succeed in operational or financial terms'.

Three elements stand out as fundamental to ExxonMobil's environmental policy. ${ }^{3}$ First, the company places a strong emphasis on being in compliance with environmental laws and regulations. This does not necessarily mean that ExxonMobil is less likely to implement self-imposed environmental standards exceeding the level of ambition in existing environmental laws. For example, its annual report states that the company should apply 'responsible standards' where environmental laws and regulations do not exist (ExxonMobil, 2000a). As pointed out by Estrada et al. (1997), however, the company does not explain what it considers to be 'responsible standards'. Also, it does not describe or discuss the potential conflict between implementation of such standards and what the company defines as its overarching goal: 'ExxonMobil is committed to being the world's premier petroleum and petrochemical company. Through the execution of long-standing, fundamental strategies that capitalize on our core strengths, the company achieves superior financial and operating results that enhance the long-term returns to our shareholders' (ExxonMobil, 2000b: 1). Nevertheless, laws and compliance are central references in ExxonMobil's statement of its environmental policy.

Second, the scientific basis of environmental regulations is a central element for ExxonMobil. It is a stated policy for the corporation to work with government and industry groups to 
develop environmental laws and regulations that are 'based on sound science'. Thus, ExxonMobil also places a strong emphasis on its own research competence, operating with a stated policy to 'conduct and support research to improve understanding of the impact of its business on the environment, to improve methods of environmental protection, and to enhance its capability to make operations and products compatible with the environment' (ExxonMobil, 2000a).

Third, an important point for ExxonMobil is that environmental policies and regulations should be developed and reviewed with a view to the broader context of environmental issues. In particular, policies should be seen in relation to the economic dimensions of environmental protection measures, including a consideration of risks, costs and benefits, and effects on energy and product supply (ExxonMobil, 2000a). Thus, it is also a stated policy for ExxonMobil 'to conduct its business in a manner that is compatible with the balanced environmental and economic needs' of the communities in which the company operates (ExxonMobil, 1999a, emphasis added).

To ensure that policy commitments are transformed into 'appropriate' action, Exxon developed its Operations Integrity Management System (OIMS) in the early 1990s (figure 3.1). These activities were stepped up in the wake of the Exxon Valdez incident in Alaska in 1989 (see chapter 4). The OIMS, which also is a central part of HSE management after the merger, serves as a structured system for 'identifying and managing [HSE] risks, for compliance with all applicable laws and regulations and for designing and operating facilities to the highest standards' (Exxon, 1999a; see also ExxonMobil, 2001a). It lays out ExxonMobil's HSE requirements for all its business units and also includes a system to maintain accountability and assess how standards are being met. The OIMS requires periodic assessments that are carried out by multidisciplinary teams of experts external to the immediate unit (ExxonMobil, 2000a).

\section{ExxonMobil's climate strategy}

ExxonMobil's emphasis on compliance, 'sound' science and consideration of economic impact permeates its approach to the problem of a human-induced climate change. According to ExxonMobil, climate projections are based on 'completely 
Figure 3.1 ExxonMobil's Operations Integrity Management System

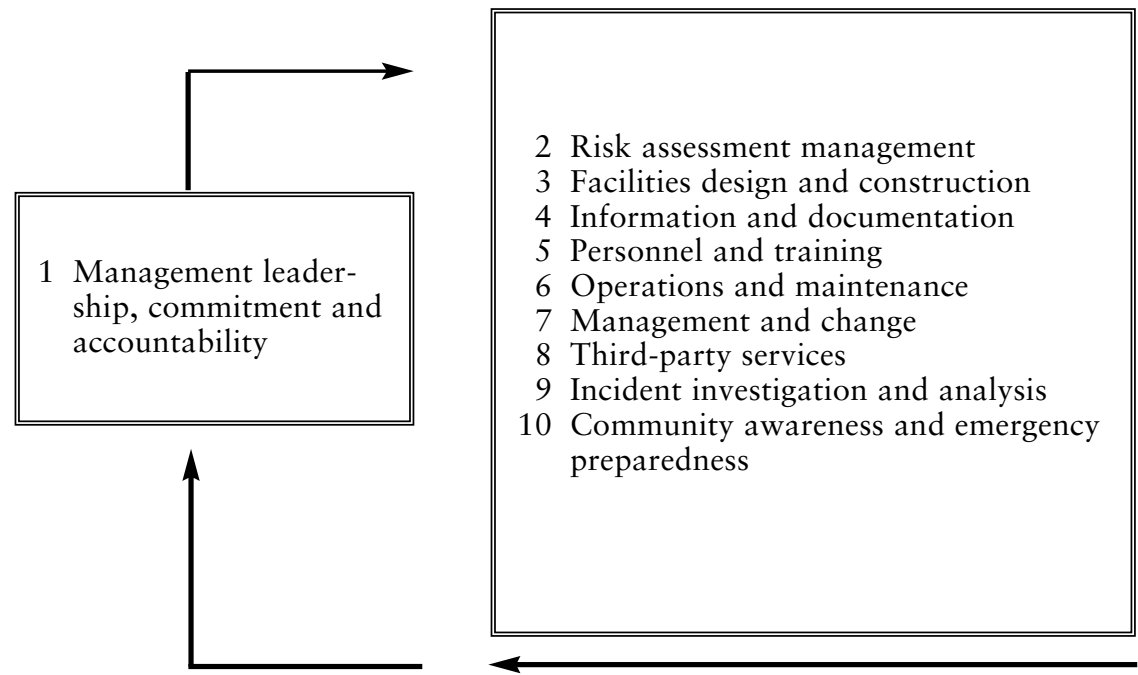

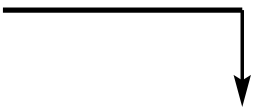

11 Operations integrity assessment and improvement

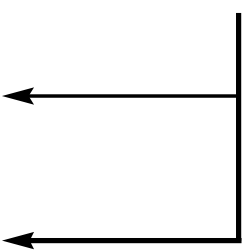


unproven climate models or more often on sheer speculation, without a reliable scientific basis' ${ }^{4}$ ExxonMobil's account of the scientific foundation of the climate problem is that it is 'good advocacy' but 'bad science' since 'the facts aren't there' (Flannery, 1999: 4). ${ }^{5}$

ExxonMobil thus opposes the Kyoto Protocol as a 'premature international initiative' that has 'the potential to cause economic harm for most nations, severely impacting some, while doing very little to influence the climate' (Flannery, 1999: 4). Three main arguments underlie ExxonMobil's opposition to the Protocol: ${ }^{6}$

1 It is too expensive. ExxonMobil presents an economic analysis that shows that the targeted reduction in fossil-fuel use would mean a 45 per cent increase in petroleum prices and cost an average American family of four about US $\$ 2,700$ a year. It is maintained that some developed countries probably would have to impose 'significantly higher fossil fuel taxes, rationing, or lifestyle changes such as mandatory car-pooling' (Flannery, 1999: 7).

2 It is unfair. The company maintains that projections show that developing countries, including China, Mexico, Brazil and India, will account for almost 70 per cent of total carbon emissions growth from 1990 to 2025. These countries are not included in the Kyoto agreement. This, ExxonMobil maintains, 'raises the question of whether that agreement is fair'.

3 It will not work. The company maintains that the warming projected by 2100 would be delayed by only some 10 years as an effect of the Kyoto Protocol and that 'far more onerous emissions reductions would be necessary if climate change proves to be serious' ${ }^{8}$

Thus, ExxonMobil considers the problem of a human-induced climate change as a 'legitimate concern', but claims that current knowledge of the science and economics of climate change does not warrant significant and mandatory GHG emissions reductions. Rather ExxonMobil argues that if emissions from human activities are altering the global climate, it is a change that is taking place on a long-term time scale. Thus, according to ExxonMobil, we have plenty of time to do more research before policy-makers address the problem. Central to ExxonMobil's argument is that the key to the solution to the climate-change 
problem is technological development. ${ }^{9}$ New technology is seen as the key enabler of combining economic prosperity and environmental protection. ${ }^{10}$ ExxonMobil has thus not adopted GHG emissions reduction targets and measures for its own operations.

Exxon, and now ExxonMobil, has given a fair amount of attention to the problem of global climate change in its public relations. The company is publishing booklets and brochures in which its view on the issue is explicated and defended, and the issue is discussed in depth in its annual reports, in HSE progress reports, and in speeches, presentations and press releases that company officials have issued on various occasions. Also, ExxonMobil has been very active in lobbying efforts against governmental GHG regulations in general and US ratification of the Kyoto Protocol in particular. From the establishment of the Washington-based GCC in 1989 - the main vehicle for the fossilfuel lobby's campaigns against GHG regulation - until its 'deactivation' in 2002, ExxonMobil functioned as a key member. ExxonMobil is also a key member of the American Petroleum Institute (API), whose policy on climate change is an almost verbatim copy of ExxonMobil's. Within the framework of these and other lobbying groups, ExxonMobil has spent a serious amount of money on PR campaigns to influence public opinion and policy-making on the issue. In the 1990s, ExxonMobil reportedly spent more than $£ 700$ million financing the $\mathrm{GCC}^{11}$ (see also chapters 5 and 6).

Being a science and technology-based corporation, ExxonMobil's emphasis on sound science, technology development and economic analyses also constitutes the foundation for the corporation's initiatives on climate change. Five areas of activity - falling within the broad categories of research and noregrets measures (measures that are justified on other grounds) are emphasised as core in a responsible path forward:

1 Conducting scientific research. ExxonMobil recognises the long-term risk of climate change. To promote a better understanding of the science of climate change, ExxonMobil conducts climate research itself as well as supporting research by others. According to the company itself, ExxonMobil scientists have 'published over 25 papers on climate change in the 
peer reviewed literature, often with distinguished academic researchers' (ExxonMobil, 2001b: 4).

2 Carrying out cost-benefit analyses of proposed responses. The corporation argues that 'citizens have a right to know the consequences of suggested governmental policies before they are implemented'. ${ }^{12}$ Recognising that policy mistakes can be serious, even limiting our opportunity to respond effectively later, ExxonMobil sees it as an important task to undertake such economic analyses.

3 Encouraging voluntary action. In 1998, Exxon established a task force to develop a comprehensive global energy management system to improve energy efficiency further at all refineries and chemical plants. In 1999, ExxonMobil had improved energy efficiency by 37 per cent in its refineries and chemical plants over the past 25 years, thus - according to its own estimate - saving an equivalent of a total of 1.7 billion barrels of oil (ExxonMobil, 2001b: 2). ExxonMobil has also made investments in co-generation of heat and power (CHP) facilities, and operates or has interest in over 2,000 megawatts of co-generation capacity worldwide - 'enough to meet the residential needs of a city with 3 million people' (ExxonMobil, 2001b: 2).

4 Investing in technological research and development. ExxonMobil invests in technological options exclusively within the framework of its fossil-fuel-based portfolio. Promising technological options (those with the potential to reduce future emissions significantly while meeting energy and economic needs) include fuels and power plants for advanced vehicles such as gasoline-electric hybrids and fuel cells; cleancoal technology for electricity generation; separation and storage of $\mathrm{CO}_{2}$ emissions; and geo-engineering to remove carbon dioxide directly from the atmosphere (ExxonMobil, 2001b: 8). Currently, investments in 'promising technological options' do not include investments in renewable energy sources. In view of 'their technology limits and excess costs', a business decision was taken many years ago to concentrate on the core energy and petrochemical businesses of the corporation. In fact, ExxonMobil strongly opposes government policies to promote renewables, as clearly expressed by ExxonMobil chairman and CEO Lee R. Raymond in 1996: 
'governments should not try to pick winners by subsidizing one alternative fuel over the other or by specifically discriminating against oil-based fuels ... The challenge for us in the petroleum industry is to do what I am doing today - stand up and tell people that oil-based fuels are plentiful, affordable, clean and getting cleaner all the time.'13 Technical and business developments in renewables are, however, followed closely, and 'if and when relevant technologies allow their commercial utilization in more than niche applications, ExxonMobil is well positioned to consider re-entry' (ExxonMobil, 2001b: 8).

5 Promoting carbon storage. Despite its scientifically uncertain long-term effect on the reduction of atmospheric concentrations of $\mathrm{CO}_{2}$, ExxonMobil pledges to protect and expand forests and to promote soil management where economically justified. Thus, ExxonMobil contributes financially to treeplanting programmes in the US and other countries (ExxonMobil, 2001b; Exxon booklet, undated.) ${ }^{14}$

Particularly when seen in the light of ExxonMobil's relentless efforts to fight down any mandatory regulation of GHG emissions, it is clear that these five activities do not in any way challenge the fossil-fuel portfolio of the company. Barring carbon storage, the activities are all no-regrets measures that are difficult to distinguish from the normal day-to-day activities of a company such as ExxonMobil. Also, their research activity is very much directed towards scientific verification of the claim that the climate does not represent a problem that needs to be addressed by governments. The climate strategy of ExxonMobil, therefore, has no long-term implications for the company's business profile or mode of operation. ExxonMobil adopted its climate strategy when the issue surfaced on the international political agenda in the late 1980s and the company has not changed its strategy since.

ExxonMobil's climate strategy summarised First, ExxonMobil does not accept that a human-induced climate change constitutes a problem that needs concerted action by governments. While it recognises that climate change is a legitimate (long-term) concern, it also emphasises that the scientific basis is still too uncertain to justify costly action. Thus, ExxonMobil does not accept that its 
activities - as a fossil-energy company - represent a documented climate risk.

Second, ExxonMobil vigorously opposes the Kyoto Protocol: while ExxonMobil does see its HSE performance as essential for its success in operational and financial terms, the problem of a human-induced climate change is not seen in these terms. On the contrary, the corporation paints a grim picture of the economic consequences of 'premature' policy action (i.e. the Kyoto Protocol) in this area - for the kind of business ExxonMobil is running, as well as for society in general. ${ }^{15}$ As we have seen, an important aspect of ExxonMobil's strategy on climate change has been active lobbying against the Kyoto Protocol's ratification in the US Senate. With its deep involvement in both the GCC and the API's activities related to climate change, ExxonMobil has represented a major actor and driving force in the campaign against the Protocol in the US.

Third, ExxonMobil has not adopted explicit GHG emissions reduction targets and measures for its own operations. The measures the company cites as its climate-related initiatives have a strong emphasis on voluntary approaches directed towards the development of new technology (within the framework of its fossil-fuel portfolio) and energy efficiency.

Fourth, as means to deal with climate change, therefore, the efforts undertaken by ExxonMobil have no implications for the mode of operation or the business profile of the company, in either the short or the long term. On the contrary, the strategy is designed to permit business as usual. Finally, the company's climate strategy has remained unaltered since it was first adopted.

In accordance with our discussion of strategy typologies in chapter 2, ExxonMobil's approach to the climate issue bears the distinct characteristics of a reactive strategy.

\section{The Royal Dutch/Shell Group of Companies}

The Royal Dutch/Shell Group of Companies is the result of an alliance made in 1907 between the Royal Dutch Petroleum Company and the 'Shell' Transport and Trading Company, plc, whereby the two companies agreed to merge their interests on a 60:40 basis while keeping separate identities. Shell was also one of the 'seven sisters', the influential oil company cartel during the 
first half of the twentieth century. Before the ExxonMobil merger, Shell was the biggest multinational oil company in the world (Estrada et al., 1997). In 2000 it ranked as the second largest multinational oil company (after ExxonMobil) and the sixth largest multinational company in the world, irrespective of sector. ${ }^{16}$ In 2000, the Shell Group had a net income of US\$12.7 billion, with total revenues of US\$149.5 billion. Currently the company conducts business in more than 135 countries in oil, gas, chemicals and renewable energy sources.

In contrast to ExxonMobil, Shell operated with a highly decentralised company structure from its origin in 1907 until 1995. From 1959 until 1995 the company was organised according to the 'McKinsey-derived matrix structure', which was unusually complex. During this period, 'most decision-making was concentrated at the level of the 100-odd local operating companies' (Neale, 1997: 96). In 1995, however, Shell began a process of reorganisation, which has led to a stronger degree of centralisation. Today, Shell is organised in five global functional core businesses that, while independent, comply with the same set of business principles. Shell's corporate headquarters - Shell International - are located in London, but the Dutch branch of the company (the Royal Dutch) owns 60 per cent of the assets.

\section{Shell's environmental policy}

Compared to ExxonMobil, the Shell Group has a more principled approach to environmental protection issues. The company has had a written environmental policy since 1969. Its environmental commitment is included and specified in Shell's General Business Principles, which have existed in written form since 1976. Within this principled framework, the company published its first Guidelines on Health, Safety and the Environment in 1977 (Estrada et al., 1997). The Shell Group's HSE commitment emphasises the following principles: ${ }^{17}$

- protecting both the environment and human populations;

- using material and energy efficiently;

- developing energy resources that are consistent with these aims;

- public reporting on performance;

- promoting best practice in its industries; 
- prioritising HSE as any other critical business activity;

- promoting a culture in which Shell employees share this commitment.

In its environmental policy, Shell seeks to transform these general principles into a practical policy. Thus, it is mandatory for every Shell company to:

- have a systematic approach to ensure compliance with the law and continuous performance improvement;

- develop clear targets for both performance and reporting;

- include HSE performance in the appraisal of all staff;

- reward the staff accordingly;

- subject all Shell's contractors and cooperative partners in joint ventures to the same environmental policy and standards.

Shell's global performance data are published in its HSE Progress Reports and have been externally verified since 1997. The verification is focused on $12 \mathrm{HSE}$ parameters including $\mathrm{CO}_{2}$ emissions, methane emissions, global warming potential (in million tonnes $\mathrm{CO}_{2}$ equivalents), flaring, sulphur dioxide emissions $\left(\mathrm{SO}_{2}\right)$ and nitrogen oxide emissions $\left(\mathrm{NO}_{\mathrm{x}}\right)$ (Shell, 2000a). Having started the development of a systematic approach to HSE management in 1998, all Shell Operating Units now have their environmental management systems certified against recognised, independent system standards, such as ISO 14001 or the European Union's Eco-Management and Audit Scheme (EMAS).

\section{Shell's climate strategy}

In its description of the climate problem as 'the most controversial and pressing environmental issue we face', Shell fully acknowledges the problem of a human-induced climate change ${ }^{18}$ (Shell, 1998b). Furthermore, immediately preceding the start of climate negotiations in Kyoto in 1997, Shell announced its support for 'prudent precautionary action to reduce man's impact on the global climate'. ${ }^{19}$ The company has later explicitly expressed its support of the Kyoto Protocol. ${ }^{20}$

Shell's position with regard to governmental action to reduce GHG emissions, however, has changed rather abruptly from a reactive stance until 1996 to the current proactive strategy. As late as July 1996, Shell, together with 119 chief executives and chairmen of mainly oil, coal and car companies, added its signa- 
ture to a letter to the US president arguing that 'the US should not agree to any of the three proposed protocols presently on the negotiating table. Your leadership on this issue is critical to assuring a continuing strong US economy' (Leggett, 1999: 246). BP was the only one of the major multinational oil companies that did not sign the letter. As we have seen, statements to the opposite effect, proclaiming support of precautionary action, started to emerge from Shell in 1997. In April 1998, the company's exit from the fossil-fuel lobby became official with its decision to withdraw from the GCC because of its disagreement with the coalition's strategy on the Kyoto Protocol: 'Following Kyoto it became clear that the respective views of the Shell companies and the GCC were too far apart ... The GCC is actively campaigning against legally binding targets and timetables as well as ratification by the US government. The Shell view is that prudent precautionary measures are called for' (Shell, 1998b). Thus, Shell's position started to change in 1997, and the company's turnaround on the climate issue was completed by 1998, after the adoption of the Kyoto Protocol. ${ }^{21}$

In September 1998, the Shell Group announced its aim to reduce GHG emissions from its own operations by 10 per cent from their 1990 levels by 2002. Shell also aims at continuing to exceed the Kyoto target by $2010 .{ }^{22}$ While Shell's GHG emissions went up in 2001, the company reported that it was still on track to reach the emissions reduction target by the end of 2002 (Shell, 2001).

Shell's commitment on climate change, outlined in the 1998 and 2000 Shell reports (1998b; 2000a), envisages six strategies to achieve the Group's long-term climate change commitment: ${ }^{23}$

1 Seek market solutions. In January 2000, Shell launched an internal GHG emissions trading system called the Shell Tradable Emission Permit System (STEPS). Businesses representing 30 per cent of the GHG emissions from the Shell Group's operations are now using tradable emissions permits to help meet their self-imposed emissions targets. ${ }^{24}$ In this system, participants are rewarded for reducing their emissions wherever the cost is lower than the price of a GHG emission permit. Shell also has as part of its strategy the provision of practical support in the development of national and interna- 
tional emissions trading systems. In February 2002, Chris Fay, former head of Shell UK, was appointed by the British government to promote the UK emissions trading scheme in which Shell participates. Finally, the company also seeks opportunities to invest in projects using the implementation mechanisms embedded in the Kyoto Protocol. Shell invests some US\$3-4 billion per year in non-Annex B countries in all of its five core business areas. ${ }^{25}$ The Shell Clean Development Mechanism (CDM) Demonstration Programme analysed and assessed the impact of CDM for eight projects. In 2001, Shell created an Environmental Products Trading Team within the Shell Trading organisation. This group is also responsible for exploring CDM opportunities for the Shell Group. ${ }^{26}$

2 Make appropriate business decisions. As nations choose different ways to meet their Kyoto targets, such actions will put a cost on carbon emissions that will influence the investment decisions of Shell companies. To meet this challenge, Shell includes the effect of a possible carbon cost in their investment decisions for new projects that could produce emissions over 100,000 tonnes a year of $\mathrm{CO}_{2}$. It will also investigate ways to reduce carbon emissions, for example by improving energy efficiency, using low-carbon fuels, and carbon sequestration or carbon removal from the atmosphere.

3 Reduce own emissions. The company will continue to invest in energy efficiency in its operations and stop the continuous disposal of unwanted gas during oil extraction (by venting and flaring) as early as possible. The Group's target is to halt continuous venting by 2003 and continuous flaring by 2008 .

4 Help customers reduce their GHG emissions. This aim will be met by increasing the availability of fuels with a lower carbon content; by offering renewable energy choices; and through work on new innovative technologies such as hydrogen. ${ }^{27}$

5 Improve understanding. Shell seeks to expand support for research into climate change and its impacts, and to promote a deeper understanding of the 'wells-to-wheels' concept, which enables a comparison of the efficiency of different fuel and engine combinations. It also seeks to take active part in public policy debates at the national and international level directly, and through industry bodies and international organisations. More generally, Shell aims at contributing to a deeper under- 
standing of the issues through the development of its social investment programmes.

6 Develop reporting and verification systems. Measurement is seen as 'fundamental' to many of the initiatives the company has proposed. Together with BP, Shell has been instrumental in developing the Greenhouse Gas Protocol Initiative, initiated by the World Business Council for Sustainable Development (WBCSD) and the World Resources Institute (WRI) in 1998, aimed at promoting internationally accepted GHG accounting and reporting standards for companies. BP and Shell have also been front runners in GHG emissions verification by third parties (Loreti et al., 2001). As a consequence of BP's and Shell's activities in this area, a growing number of companies have shown interest in emissions verification. The companies' verification systems have also been important for public authorities' requirements to environmental reporting.

Shell's initiatives on climate change have implied significant changes in its mode of operation and business orientation. First, a central aspect of Shell's strategy on climate change is 'decarbonisation' of fossil fuels - both through improved technology and through a switch from coal to oil to gas (see, for instance, Fay, 1997). In line with such an endeavour, Shell announced in 1997 that the group's coal assets were under strategic review. The sales of its coal assets were completed in 2000. With the 1997 announcement, Cor Herkströter, chairman of Royal Dutch Shell, also reportedly 'made plain he backs world moves towards "decarbonisation" - getting rid of one of the biggest causes of the greenhouse effect'. ${ }^{28}$

The most visible result of Shell's position on climate change is the 1997 restructuring, when Shell International Renewables was established as a fifth core business activity. The purpose of this restructuring was to consolidate the Group's activities in solar power, biomass (wood-based) power and forestry, and it underscores the Group's strategic direction, which is 'to provide energy and develop resources efficiently, responsibly and profitably in order to help meet the world's growing needs, and to do so in a way that contributes to sustainable development'. ${ }^{29}$ Shell maintains that renewables will constitute the main energy source of the future. ${ }^{30}$ With the establishment of Shell International 
Renewables, Shell aimed to capture a 10 per cent share of the renewables market before 2005. Shell planned to invest more than US\$0.5 billion over a five-year period from 1997 in renewable resources. This, however, represents only a small fraction of the company's investment, for instance, in oil exploration.

As noted in chapter 2, it is difficult to assess the cause-effect relationship between a proactive strategy to climate change and a strategy of decarbonisation of fuels and introduction of renewables. Shell itself has presented its divestment in coal as an integral part of its climate strategy. While these events all took place in 1997, and hence at approximately the same time, Shell's shift in climate strategy was nevertheless announced before its decision to divest its coal assets and invest in renewables (although the company remained a member of the GCC until April 1998). On the basis of the chronological order of these events and Shell's own stated motivation, Shell's actions on coal and renewables are thus treated as effects of a new strategy in this analysis, rather than as causes of its climate strategy.

Moreover, with regard to investments in renewable energy sources, Shell emphasises business opportunities in this area as its main motivation. Shell's investment in renewables should thus also be seen as a response to the one main challenge, as Shell sees it, of finding commercial paths to new energy futures. ${ }^{31}$ The commercial aspect, therefore, is one central focus, and reportedly a main motivation for Shell's position on and investments in environmental protection in general and the climate-change issue in particular. Shell invests in greenhouse gas reductions and renewable resources because they see such an investment as a business opportunity. ${ }^{32}$

Shell's emphasis on the commercial aspects of environmental protection and sustainable development is also reflected in a strong support for and emphasis on the development of 'achievable targets', primarily through market-based instruments and measures to reduce emissions. ${ }^{33}$ In 1997, then chairman and chief executive of Shell UK Ltd, Chris Fay, outlined four groups of instruments - in prioritised order - that could be used to reduce and change energy-consumption patterns:

- ending subsidies for coal production in countries like Germany, China and India; 
- tackling other artificial pricing structures that encourage highcarbon fuels;

- ensuring that there are competitive electricity markets so that new technologies can find market niches;

- looking at other consumption-dampening mechanisms such as carbon taxes, tradable carbon permits and so on.

According to Fay, it is important to ensure that measures to reduce consumption 'are not disguising revenue raisers', that such measures 'encourage competitive markets, not distort them', and that they thus 'must be aimed at pushing the energy industry along the development path that is already clearly evident toward lower carbon content'. ${ }^{34}$

Shell's climate strategy summarised First, Shell acknowledges the problem of a human-induced climate change and bases its climate strategy on the precautionary principle. Shell thus acknowledges that its activities in the coal, oil and gas industry represent an environmental risk. ${ }^{35}$

Second, Shell explicitly supports the Kyoto Protocol and has been a front runner together with BP in promoting reporting, verification and emissions trading.

Third, Shell has adopted targets and measures to reduce GHG emissions from its own operations. The company aimed at a 10 per cent reduction from 1990 levels by 2002. One important instrument to achieve this goal was the establishment of Shell's internal emissions trading scheme. Another important measure adopted by Shell was to calculate an anticipated carbon cost in investment decisions for new projects that would emit more than 100,000 tonnes of $\mathrm{CO}_{2}$ a year.

Fourth, Shell's climate strategy has had and will continue to have implications for the business orientation of the company: Shell divested its coal activities in 2000 and was reorganised in 1997, with the establishment of Shell International Renewables as a fifth core business area. The primary motivation for this establishment was the market potential judged by Shell to be associated with renewables and a future renewables market. Perhaps equally important for Shell's future business profile is the Group's decision to include anticipated carbon costs in its investment decisions for new projects. Thus, Shell has reviewed and revised its business profile in response to the climate problem. ${ }^{36}$ It is inter- 
esting to note that Shell's strategy on this issue is similar to that chosen by the other European oil giant, BP (Rowlands, 2000).

In accordance with our discussion of strategy typologies in chapter 2, Shell's climate strategy can thus be characterised as proactive both in relation to the criteria selected here and in comparison with ExxonMobil's. Shell's approach to climate strategy underwent a complete reversal during the 1990s, however, from a reactive approach until 1996 to the current proactive approach that the company has adopted since 1997/1998.

\section{Statoil Corporation}

Statoil is a youngster compared to ExxonMobil and Shell. In 1972 the Norwegian authorities established Statoil as a fully state-owned oil company for the exploration, production, refining and marketing of the petroleum resources found on the Norwegian continental shelf. Rapid growth ensued in the 1980s, as Statoil was given the responsibility of running operations at Gullfaks in 1981 and Statfjord in 1987. During the 1990s, the company gradually expanded its international upstream operations and currently operates in 25 countries. With its operating revenues in 2000 of 208 billion Norwegian kr. (US\$23.5 billion), Statoil is a dwarf among giants on the international scene. Its net income in 2000 was 11.3 billion Norwegian kr. (US\$1.3 billion). ${ }^{37}$ The company, however, is the world's second largest seller of crude oil and a significant supplier of natural gas to Europe. The company ranks as the biggest retailer of petrol and other oil products in Scandinavia. Moreover, Statoil was responsible for managing the Norwegian state's direct financial interest (SDFI) on the Norwegian continental shelf from its establishment in 1985 until 2001. The Statoil and SDFI combined portfolio ranks as the fourth largest of OECD oil companies with regard to both oil and gas production and oil and gas reserves (after ExxonMobil, BPAmoco/Arco and the Shell Group) (Statoil, 1999b).

Statoil was a fully state-owned company from its establishment in 1972 until April 2001, when Norwegian authorities decided to privatise Statoil partially and list the company on the stock exchange. Initially, only 18.2 per cent of the company was sold to private shareholders, but the Norwegian parliament will over 
time reduce the state's ownership to two-thirds of the shares. Norwegian authorities also decided to sell approximately 20 per cent of the value of the SDFI, of which Statoil bought 15 per cent. A new state-owned company, Petoro, was established to manage the remaining shares of the SDFI. Statoil, however, remains responsible for selling the SDFI's oil and gas volumes. ${ }^{38}$

\section{Statoil's environmental policy}

Statoil's systematic approach to environmental issues is of relatively recent origin: the early 1990s. In 1991, the company adopted the 16-point charter for sustainable development drawn up by the ICC. Also in 1991, a project to identify environmental challenges and to strengthen the company's work on environmental issues was initiated. An environmental department of five people was established, obliged to report to the corporate management (Estrada et al., 1997). Today, the management system for HSE forms an integrated part of Statoil's total management system.

The company also issued its first environmental report in 1991 - Responding Actively to Environmental Challenges - emphasising humankind's responsibility for the environment and the necessity of keeping development within the bearable limits of nature in order to preserve the common environment. Today, under the slogan 'A high performance in HSE has a value in itself', Statoil adopts an 'ethical commitment to preserve human life and health, protect the environment and safeguard material and financial interests as well as our reputation in all circumstances'. ${ }^{39}$

A key element in Statoil's HSE management system is registration, reporting and assessment of relevant data. Statoil has nine group-wide HSE performance indicators, five of which are related to the external environment: oil spills, $\mathrm{CO}_{2}$ emissions, $\mathrm{NO}_{\mathrm{x}}$ emissions, energy consumption and the waste recovery factor. These indicators are reported annually for all Statoil-operated activities (oil spills are reported quarterly) (Statoil, 2000).

Statoil's investments in environmental measures, however, are pragmatically spent on research, installation of new machinery and upgrading of old equipment (Statoil, 1998). The research effort is primarily focused on an increased knowledge about emissions from its own operations and associated health and environ- 
mental effects, and the development of products, processes and technology to reduce emissions and adverse effects.

\section{Statoil's climate strategy}

The issue of global climate change has been given attention ever since the publication of Statoil's first environmental report in 1991. Today Statoil's slogan is 'The issue for Statoil is not whether the world faces a climate problem, but how it can be overcome.' 40 Thus, Statoil seems to accept readily the scientific basis of the climate-change problem. Statoil explicitly states that it will make active efforts to stay up to date on developments in scientific knowledge about the greenhouse effect, and that the company will continue, together with others, to contribute to an understanding of the social, economic and competitive impacts of climate policies aimed at the petroleum industry and the energy market. Moreover, it will actively participate in an open collaboration with the authorities to find effective solutions for abating GHG emissions. ${ }^{41}$

Statoil has announced its support for the Kyoto Protocol, and says that it provides a good initial basis for global cooperation on a rational climate policy (Statoil, 1997). The company finds the reduction objective agreed upon in Kyoto ambitious, but asserts that it is achievable if industry and the authorities cooperate in identifying realistic measures (Statoil, 1997). Accordingly, Statoil strongly supports the Kyoto mechanisms, which 'will make it easier to come up with cost-effective solutions and help to ensure that more and better action is taken globally' (Statoil, 1997). Since 1991, before the Earth Summit in Rio and the establishment of the UNFCCC, Statoil has emphasised the importance of flexibility mechanisms in environmental management (Statoil, 1992: 4). Such programmes are especially crucial to Statoil and the rest of the Norwegian petroleum industry, given the existing levels of efficiency and high cost of further emissions reductions on the Norwegian shelf relative to other petroleum-extracting provinces (Statoil, 1998: 4).

Statoil's corporate level goal is 'zero' emissions that cause lasting damage or have a negative impact on the environment (Statoil, 1999a: 33). In practice, carbon dioxide, nitrogen oxide and volatile organic compounds (VOC) emissions cannot be entirely eliminated. The exact implications of this 'goal', there- 
fore, are difficult to judge. In 1997, Statoil adopted a target to cut $\mathrm{CO}_{2}$ emissions by 30 per cent over the next decade (by 2010) relative to a 'business as usual scenario' (the level emissions would reach with the currently existing technology and practice) (Statoil, 1998: 2). In 2000, this target was modified. The current target is 'to trim 1.5 million tonnes of carbon dioxide equivalent from its annual greenhouse gas emissions by 2010 compared with "business as usual" based on 1997 technology' (Statoil, 2000). This does not mean, therefore, that Statoil intends to cut its $\mathrm{CO}_{2}$ equivalent emissions by 1.5 million tonnes annually in absolute terms, but rather to cut 1.5 million tonnes of $\mathrm{CO}_{2}$ equivalent emissions annually as compared to what the levels would have been with 1997 technology. It is indicated that this goal would correspond to a cut of 'roughly $15 \%$ from present forecasts for Statoil's share of global emissions in 2010' (Statoil, 2000, emphasis added). Again, therefore, the target is stated in relative terms relative to an unspecified 'business as usual' baseline scenario. This is a highly ambiguous goal.

International operations are expected to account for a large proportion of the planned emission cuts. Also, energy saving and stopping permanently lit flares will provide major emissions reductions, according to the Statoil environment vice-president, Knut Barland. ${ }^{42}$ The focus on technological innovation as a means to fulfil its reduction target became clear when the company revised its goal. On that occasion, Knut Barland commented that the level of ambition in the target was reduced because 'new knowledge has shown that the effect of innovative technology is lower than expected'. ${ }^{43}$

While Statoil does report its $\mathrm{CO}_{2}$ emissions, it does not report its $\mathrm{CO}_{2}$ equivalent emissions - the measure in which its reduction target is stated (which is a common measure for all GHG emissions, thus also including emissions of other GHGs such as methane and nitrous oxide $\left.\left[\mathrm{N}_{2} \mathrm{O}\right]\right)$. Therefore it is difficult to judge whether the company is on track to achieve its goal. Its $\mathrm{CO}_{2}$ emissions, however, increased by 1.1 million tonnes from 2000 to 2001 (Statoil, 2001). In this perspective, Statoil's general corporate goal of 'zero' emissions that cause lasting damage seems rather meaningless, with little or no practical implications for the operations of the company.

In 1997, Statoil launched its $\mathrm{CO}_{2}$ programme, a three-year 
project to identify ways of reducing emissions of this GHG. The main emphasis in the 600 million Norwegian kr. programme was on the development of new technology, making better use of existing solutions, and carbon storage. Thus, Statoil's initiatives on climate change are based well within the framework of their fossil-fuel portfolio.

Statoil's investment in renewables has been modest. In 1997, the company invested in Biovarme, a bioheat company, and started 'Three steps ahead for environmentally sound energy', which maps out investment possibilities in renewables (Greenpeace International, 1998: 54). Also, Statoil is exploring opportunities for producing and marketing renewable forms of energy, such as wind power and biomass (Statoil, 1998: 12). The company is currently collaborating with Norske Skog in the production and sale of biofuels, which are expected to reach an annual production of 8,000 tonnes (Statoil, 1999a: 36). Statoil, along with other oil companies, is also collaborating on fuel-cell research with auto and fuel-cell manufacturers (Statoil, 1999a: 35). Thus, unlike, for instance, BP and Shell, Statoil has not devoted any resources to solar energy research, and in April 1998, Statoil's HSE director reportedly stated that 'renewable energy is not our business' (Greenpeace International, 1998: 54). This is illustrated by the company's decision in January 2000 to withdraw from a joint venture project on wind power in Norway because it could not see any future profitability in the product. ${ }^{44}$

Today, Statoil exports produced gas to continental Europe. The company has in recent years, however, explored the possibility of participating in natural-gas-based electricity generation schemes at home and abroad. For Statoil the prospect of integrating further down the gas chain is considered important for optimising the value of natural gas. Accordingly, Statoil, Norsk Hydro and Statkraft - the largest Norwegian supplier of hydropower - established Naturkraft in 1994. The idea is to produce electricity derived from natural gas and sell it in combination with hydropower. For this purpose, Naturkraft has been working for political and public acceptance of two gas-fired power plants on the west coast of Norway (see chapter 5). The plan has met with considerable resistance from the Norwegian environmental movement, which finds the resulting increase in Norwegian $\mathrm{CO}_{2}$ emissions unacceptable, not least after the 
advent of the Kyoto Protocol. However, after a long and polarised political debate (in which one government resigned on this issue), the initiators have achieved a concession to build the plants. The plants have not yet been built, however, mainly because costs are too high and electricity prices too low for the business to be profitable.

Statoil's climate strategy has been developed gradually since 1991. Thus, the strategy has undergone incremental changes during this period. Given the high degree of ambiguity in the company's approach to climate change, however, we cannot say that Statoil's approach has moved towards a larger degree of 'proactivism'. On the contrary, given the company's revision of its $\mathrm{CO}_{2}$ emissions reductions target towards a lower level of ambition, Statoil's climate strategy has moved back and forth since 1991, and has, above all, remained equally ambiguous throughout the period.

Statoil's climate strategy summarised First, Statoil accepts that human-induced climate change represents a problem that requires concerted action by governments. Second, the company declares its support for the Kyoto Protocol.

Third, Statoil has adopted a self-imposed GHG emissions reduction commitment. This however, is highly ambiguous, since the reduction goal is stated not in absolute terms but rather in relation to an unspecified 'business as usual' baseline. Statoil plans to implement this target by focusing on technological options to reduce emissions, such as enhanced energy efficiency, technological innovation and carbon storage. Its climate initiatives, therefore, do not challenge the company's fossil-fuel portfolio. This is particularly evident with regard to the circumstances around the modification of Statoil's $\mathrm{CO}_{2}$ reduction target in 2000.

Fourth, even though Statoil clearly acknowledges the climate problem, supports the Kyoto Protocol and has adopted selfimposed emissions reductions, the level of commitment in this strategy may nevertheless be characterised as moderate. The strategy that Statoil has chosen on the climate issue has no significant (long-term) implications for the company's business orientation.

Finally, while the strategy has developed incrementally since 
1991, we cannot trace any significant changes in Statoil's approach towards either a more proactive or a more reactive strategy. Rather, the company's climate strategy has moved back and forth and remained equally ambiguous throughout the period.

In terms of our discussion of strategy typologies in chapter 2, therefore, Statoil seems to lie between a reactive and a proactive strategy, as an 'intermediate' between ExxonMobil and Shell. It has adopted a proactive rhetoric on the issue, but the strategy and choice of means to transform the rhetoric into action are less substantial than Shell's.

\section{Comparison of the climate strategies of the three companies}

There are striking differences in the climate strategies adopted by the three companies, particularly between ExxonMobil and Shell. And these differences go far beyond mere rhetoric. In many respects ExxonMobil and Shell represent opposite extremes, with ExxonMobil on the reactive end of the continuum and Shell on the proactive end. Statoil has adopted a strategy that lies in the middle of this spectrum, with similarities to both ExxonMobil and Shell.

Above, we have assessed the climate strategies of the three companies in terms of four main indicators: their acknowledgement of the problem of a human-induced climate change; their position with regard to the Kyoto Protocol; the adoption of targets and measures to reduce GHG emissions from their own operations; and the level of ambition and commitment in their strategies, judged in terms of the degree of reorientation in core business areas implied by the strategies. In addition, we have assessed the degree to which the companies' climate strategies have undergone changes during the last decade.

\section{Acknowledgement of problem and position on the Kyoto \\ Protocol}

Of the three companies, ExxonMobil is the most reluctant in its acknowledgement of a prospective human-induced climate change. The company acknowledges that the possibility of human-induced climate change is a 'legitimate concern', but claims it is far from a scientifically established fact. It does not 
accept that the problem is sufficiently scientifically substantiated to legitimise costly policy regulation. Accordingly, ExxonMobil is also explicitly opposed to the Kyoto Protocol. The Shell Group and Statoil, on the other hand, both acknowledge the climate problem as a real problem requiring concerted action by governments. Both corporations explicitly support the Kyoto Protocol.

\section{Self-imposed GHG emissions reduction targets and measures}

Given ExxonMobil's reluctant acknowledgement of the climate problem as a 'legitimate concern' and its explicit opposition to the Kyoto Protocol, it is no surprise that it has not adopted any voluntary targets for GHG emissions control or reduction for its own operations. On the contrary, its position is that if there indeed is a climate problem, it is a long-term problem to which there is plenty of time to develop appropriate responses.

Both the Shell Group and Statoil have announced GHG emissions reduction targets for their own operations. Shell adopted an aim of reducing GHG emissions by 10 per cent from their 1990 levels by 2002. According to its 2001 reporting, the company was set to succeed in achieving this aim, even though its GHG emissions rose during 2001. Statoil, on the other hand, adopted in 1997 a highly ambiguous target of a 30 per cent reduction in $\mathrm{CO}_{2}$ emissions over the next decade (by 2010) relative to the level anticipated with currently existing (1997) technologies and practice. Moreover, in 2000 , this target was modified to an equally ambiguous target of an annual reduction of 1.5 million tonnes of $\mathrm{CO}_{2}$ equivalent emissions by 2010, also as compared to anticipated 'business as usual' emissions levels (with 1997 technology). While the target was stated in terms of $\mathrm{CO}_{2}$ equivalents (thus including other gases than $\mathrm{CO}_{2}$, for instance, methane and $\mathrm{N}_{2} \mathrm{O}$ ), Statoil does not report its $\mathrm{CO}_{2}$ equivalent emissions. The $\mathrm{CO}_{2}$ emissions of the company, however, rose by 1.1 million tonnes from 2001 to 2002. It is therefore difficult to judge whether the company's voluntary reduction target has any practical implications for Statoil's operations.

The most important measures adopted by Shell to implement its reduction target are the establishment of an internal scheme for emissions trading and a revision of its investment decision procedure to include a calculated carbon cost for future projects. Statoil's main measure to implement its target is technological innovation. 
Reorientation in business areas

ExxonMobil's current position does not involve strategies explicitly designed to meet a climate problem. Its response to climate change is thus currently heavily dominated by research activities - conducted by itself, in cooperation with other research institutions or through the provision of funds to build 'external capacity'. Other activity in response to this problem mainly consists of technology development to improve energy efficiency and to decarbonise fuels. ExxonMobil does not publish its GHG emissions. Currently, therefore, ExxonMobil's strategy is more or less 'business as usual' and does not show any sign of commitment that might have long-term implications for its business orientation. This strategy is combined with vigorous efforts to defeat any mandatory control on GHG emissions (see chapters 5 and 6).

The Shell Group has also approached the problem by improving energy efficiency and decarbonisation of fuels - for instance, through increases in the provision of natural gas supplied through liquefaction, pipelines and conversion to liquid fuels. In contrast to ExxonMobil, however, Shell's decarbonisation strategy has had implications for its business orientation: in 2000, Shell divested its coal assets. With its investment in renewable energy resources (photovoltaics and biomass energy), the Shell Group, moreover, has adopted a strategy that has already implied a reorganisation of the Group and a reorientation in its business profile. Finally, Shell has changed its routines for investment decisions for new projects to include anticipated costs associated with significant $\mathrm{CO}_{2}$ emissions. In contrast to ExxonMobil, therefore, it may be argued that Shell's approach to climate change will have much more significant long-term implications in terms of a business reorientation and thus reflects a higher level of ambition.

While Statoil's rhetoric on the climate issue is similar to Shell's (the acknowledgement of the problem, support for the Kyoto Protocol and adoption of voluntary reduction commitments), the company's actions on this issue are more similar to ExxonMobil's. Statoil's strategy towards climate change is largely one of research and technological innovation. To the extent that the company intends to honour its self-imposed reduction target, the reduction will primarily come as a result of technological innovation. This is particularly demonstrated by the circumstances under which Statoil modified its GHG emissions reduction target in 2000. The company has also 
made no major investments in renewable energy sources. Its climate strategy, therefore, seems to a much lesser extent than Shell's to imply significant investment changes or corporate reorientation. The strategies of the three companies are summarised in table 3.1 below.

\section{Changes in strategies since the start of the 1990s}

Of the three companies, only Shell's strategic approach to climate change has undergone a marked and significant change. Shell changed its strategy rather abruptly from a reactive approach until 1996 to a proactive one from 1997/1998. Statoil's climate strategy has been developed incrementally since 1991, but has moved back and forth and has been equally ambiguous throughout the period. ExxonMobil's climate strategy has remained unaltered since it was first adopted in the late 1980s.

Table 3.1 Summary of the climate strategies of ExxonMobil, the Shell Group and Statoil

\begin{tabular}{|c|c|c|c|c|}
\hline Company & $\begin{array}{l}\text { Acknow- } \\
\text { ledgement } \\
\text { of problem }\end{array}$ & $\begin{array}{l}\text { Position on } \\
\text { the Kyoto } \\
\text { Protocol }\end{array}$ & $\begin{array}{l}\text { GHG } \\
\text { emission } \\
\text { reduction } \\
\text { target and } \\
\text { measures }^{\mathrm{a}}\end{array}$ & $\begin{array}{l}\text { Reorientation in } \\
\text { business areas }\end{array}$ \\
\hline ExxonMobil & $\begin{array}{l}\text { Reluctant: } \\
\text { 'legitimate } \\
\text { concern' }\end{array}$ & $\begin{array}{l}\text { Explicit } \\
\text { opposition }\end{array}$ & No & $\begin{array}{l}\text { Low: no implications } \\
\text { for mode of } \\
\text { operation or } \\
\text { business orientation }\end{array}$ \\
\hline Shell Group & Yes & $\begin{array}{l}\text { Explicit } \\
\text { support }\end{array}$ & Yes & $\begin{array}{l}\text { High: potentially } \\
\text { significant long-term } \\
\text { implications for } \\
\text { mode of operation } \\
\text { and business } \\
\text { orientation }\end{array}$ \\
\hline Statoil & Yes & $\begin{array}{l}\text { Explicit } \\
\text { support }\end{array}$ & $\begin{array}{l}\text { Yes, but } \\
\text { ambiguous }\end{array}$ & $\begin{array}{l}\text { Medium: shift of } \\
\text { emphasis and change } \\
\text { in routines, but no } \\
\text { long-term } \\
\text { implications for } \\
\text { mode of operation } \\
\text { and business } \\
\text { orientation }\end{array}$ \\
\hline
\end{tabular}

Note: ${ }^{a}$ Beyond 'no regrets'. 
Our assessment and comparison of the three companies' climate strategies thus shows that it is not only the rhetoric that divides the companies in this issue area. Shell's climate strategy is supported by a set of actions that already have implied a significant reorientation in the company's business profile, and will continue to have implications for the future. In the next chapter, we explore the extent to which differences between the companies themselves can account for these observed differences in their climate strategies.

\section{Notes}

1 Fortune, 2002, Global 500. Source: www.fortune.com (accessed 31 May 2002).

2 Shelley Moore, 'What's new and better about ExxonMobil?', Lamp (ExxonMobil publication), Autumn 1999. Source: www. exxon.mobil.com/news/publications/fall99_lamp/04newandbetter. html.

3 Personal communication with Brian P. Flannery and Gary F. Ehlig, ExxonMobil Corporation, Irving, Texas, March 2000.

4 Booklet issued by Exxon Corporation: 'Global Climate Change: Everyone's Debate', undated. Source: www.exxon.com/exxoncorp/ overview/viewpoint/global_climate/global/globe1.htm (accessed 23 August 1999).

5 See also 'Remarks by Dr. Brian Flannery on climate change', 11 March 1999. Source: www.exxon.com/exxoncorp/news/speeches/ speech_031199.html (accessed 12 October 1999).

6 Personal communication with Brian P. Flannery and Gary F. Ehlig, ExxonMobil Corporation, Irving, Texas, March 2000.

7 Booklet issued by Exxon Corporation: 'Global Climate Change: Everyone's Debate', undated. Source: www.exxon.com/exxoncorp/ overview/viewpoint/global_climate/global/globe1.htm (accessed 23 August 1999).

8 Booklet issued by Exxon Corporation: 'Global Climate Change: Everyone's Debate', undated. Source: www.exxon.com/exxoncorp/ overview/viewpoint/global_climate/global/globe1.htm (accessed 23 August 1999).

9 Personal communication with Brian P. Flannery and Gary F. Ehlig, ExxonMobil Corporation, Irving, Texas, March 2000.

10 Booklet issued by Exxon Corporation: 'Global Climate Change: Everyone's debate', undated. Source: www.exxon.com/exxoncorp/ overview/viewpoint/global_climate/global/globe1.htm (accessed 23 
August 1999); Flannery, 1999; ExxonMobil press release dated 18 September 1999, 'Mobil report says time, technology and global participation needed to stabilize atmospheric $\mathrm{CO}_{2}$ concentration'; ExxonMobil press release dated 15 February 2000, 'ExxonMobil Executives: oil industry technology can deliver economic prosperity and a cean environment'; ExxonMobil, 'Global climate change: ExxonMobil views', April 2001. Source: www.exxon.mobil.com (accessed 27 May 2002).

11 Guardian, 5 April 2002: 'Oil giant bids to replace climate expert'.

12 Booklet issued by Exxon Corporation: 'Global Climate Change: Everyone's Debate', undated. Source: www.exxon.com/exxoncorp/ overview/viewpoint/global_climate/global/globe1.htm (accessed 23 August 1999).

13 Lee R. Raymond, 'Energy, the economy, and the environment: moving forward together', speech at the Economic Club of Detroit, 6 May 1996. Source: www.exxon.com/exxoncorp/news/speeches/ speech_050696.html (accessed 12 October 1999).

14 Booklet issued by Exxon Corporation: 'Global Climate Change: Everyone's Debate', undated. Source: www.exxon.com/exxoncorp/ overview/viewpoint/global_climate/global/globe1.htm (accessed 23 August 1999).

15 Personal communication with Brian P. Flannery and Gary F. Ehlig, ExxonMobil Corporation, Irving, Texas, March 2000.

16 Fortune, 2002, Global 500. Source: www.fortune.com (accessed 31 May 2002).

17 Source: www.shell.com/royal-en/content/0,528,25583-51073,00.html (accessed 19 March 2001).

18 Personal communication with Gerry Matthews, Shell International, Washington, DC, March 2000.

19 Phil Watts, 'Contributing to sustainable development', statement issued 18 November 1997. Source: www.shell.com/library/ speech/0,1525,2302,00.html (accessed 22 November 1999).

20 See, for instance, 'Progressing towards sustainable development Shell exploration and production's commitment in action', Shell publication issued 2 November 2000. Source: www.shell.com (accessed 31 May 2002).

21 Personal communication with Gerry Matthews, Shell International, Washington, DC, March 2000.

22 See, for instance, 'Taking action on sustainable development: climate change'. Source: www.shell.com/values/content/0,1240, 1215-3397,00.html (accessed 10 January 2000).

23 Source: www.shell.com/values/content/0,1240,1215-3397,00.html (accessed 10 January 2000); personal communication with Gerry Matthews, Shell International, Washington, DC, March 2000. 
24 'Shell Tradable Emission Permit System: an overview', issued 27 January 2000, available at www.shell.com/download/steps/steps.pdf.

25 In the Kyoto Protocol, the quantified emission limitation or reduction commitments by the parties are listed in Annex B of the agreement. Thus, parties that have taken on such commitments are often referred to as Annex B countries. In the UNFCCC, the parties that have taken on the commitments defined in Article 4.2 of the Convention are listed in Annex I of the Convention and are thus often referred to as Annex I countries.

26 Source: www.shell.com.

27 Mark Moody-Stuart, 'The importance of the Kyoto mechanisms for sustainable development and business', speech issued 8 October 1999. Source: www.shell.com/library/speech/0,1525,4407,00.html (accessed 22 November 1999).

28 Guardian, 19 November 1997, 'Shell beefs up green moves'. Source: www.globalpolicy.org/finance/alternat/carbon/ct11_19.htm (accessed 31 May 2002).

29 Jeroen van der Veer (group managing director, Royal Dutch/Shell Group) and Jim Dawson (president, Shell International Renewables), 'Shell International Renewables: bringing together the Group's activities in solar power, biomass and forestry', press conference, London, 6 October 1997. Booklet published by the Shell Group.

30 Guardian, 19 November 1997, 'Shell beefs up green moves'. Source: www.globalpolicy.org/finance/alternat/carbon/ct11_19.htm (accessed 31 May 2002).

31 Mark Moody-Stuart, 'The importance of the Kyoto mechanisms for sustainable development and business', speech issued 8 October 1999. Source: www.shell.com/library/speech/0,1525,4407,00.html (accessed 22 November 1999).

32 Jeroen van der Veer, (group managing director, Royal Dutch/Shell Group), 'Sustainable solutions support sustainable business', speech issued 26 May 1999. Source: www.shell.com/library/speech/0,1525, 3893,00.html (accessed 22 November 1999).

33 Personal communication with Gerry Matthews, Shell International, Washington, DC, March 2000; Chris Fay (chairman and chief executive, Shell UK Ltd), 'Achievable targets needed', speech at the CBI Panel Debate, 'Climate Change - a Taxing Business?', at the CBI National Conference, Birmingham, 10 November 1997. Source: www.shell.co.uk/news/speech/spe_achievable.htm (accessed 22 November 1999).

34 Chris Fay (chairman and chief executive, Shell UK Ltd), 'Achievable targets needed', speech at the CBI Panel Debate, 'Climate Change a Taxing Business?', at the CBI National Conference, Birmingham, 
10 November 1997. Source: www.shell.co.uk/news/speech/ spe_achievable.htm (accessed 22 November 1999).

35 Personal communication with Gerry Matthews, Shell International, Washington, DC, March 2000.

36 Personal communication with Gerry Matthews, Shell International, Washington DC, March 2000.

37 Thus, ExxonMobil's net income in 2000 was roughly 13 times larger than Statoil's. Shell's net income in the same year was roughly 10 times larger than Statoil's.

38 Source: www.statoil.com (see also Norwegian White Paper no. 36, December 2000).

39 Source: www.statoil.com.

40 'Statoil and climate policy'. Source: www.statoil.com.

41 'Statoil and climate policy'. Source: www.statoil.com.

42 Statoil press release, 26 May 2000. Source: www.statoil.com.

43 Statoil press release, 26 May 2000. Source: www.statoil.com.

44 Stavanger Aftenblad, 28 January 2000. 